\title{
Biocontrol of Pseudomonas syringae pv. syringae affecting citrus orchards in Tunisia by using indigenous Bacillus spp. and garlic extract
}

\author{
Imen Mougou and Naima Boughalleb-M'hamdi ${ }^{*}$ (1)
}

\begin{abstract}
Citrus blast and black pit that became increasingly important bacterial diseases are caused by Pseudomonas syringae pv. syringae. This study aimed to evaluate the antibacterial potential of Bacillus species strains and garlic extracts against two P. syringae isolates (BAT13 and DAPP-PG115). The Bacillus species strains were isolated from symptomless citrus leaves. Under in vitro conditions, 21 Bacillus species strains and garlic extract displayed antibacterial activity against the pathogen. Under greenhouse conditions, antagonistic bacteria, garlic extract, and copper sulfate confirmed their antimicrobial effect on $P$. syringae and reduced significantly the extend of stem necrosis 10 weeks after inoculation by BAT13 up to $60.55,56.11$, and $45.83 \%$, and by DAPP-PG115 up to $70.83,62.5$, and $46.52 \%$, in respect to relevant treatments. Garlic extract was the most effective treatment in our hands, and it suggests that Allium sativum extract could be used to control and prevent infection by the pathogen.
\end{abstract}

Keywords: Pseudomonas syringae, Antagonistic bacteria, Allium sativum, Biological control, Citrus bacteriosis

\section{Background}

Citriculture represents a strategic sector in Tunisia that covers around 24,000 ha with c. 6.4 million trees. Annual production is estimated around 300,000 tons of fruit (DGPA 2016). Among the bacterial diseases that pose a threat to citrus and reduce the yield are the citrus blast and black pit, caused by Pseudomonas syringae pv. syringae (Snowdon 1990). Beiki et al. (2016) reported new citrus pathogenic strains of Pseudomonas orientalis, P. simiae, P. lurida, P. moraviensis, and P. monteilii. Blast results in expanding lesions on citrus leaves and stems leading to defoliation of trees in severe attacks. Black pit results in dark-colored, sunken blemishes on fruits particularly on lime and lemon (Fawcett et al. 1923). In Tunisia, P. syringae pv. syringae causing citrus blast and black pit was first reported by Boubaker (1986) on sour orange, Citrus aurantium, then by Abdellatif

\footnotetext{
* Correspondence: n.boughalleb@laposte.net; n.boughalleb2017@gmail.com Département des Sciences Biologiques et de la Protection des Plantes, UR13AGR03, Université de Sousse, Institut Supérieur Agronomique de Chott Meriem, 4042 Sousse, Tunisia
}

et al. (2015) on Citrus sinensis and C. limon. Moreover, recent investigation demonstrated that citrus cultivars Thompson Navel and New Hall were most susceptible. While the cultivar Eureka appeared to be less susceptible to citrus blast disease. Cultivars Eureka and Swett Lime seemed to be most susceptible to black pit disease (Mougou and Bougalleb-M'hamdi 2016a). Weeds and plant debris were shown to be a source of $P$. syringae inoculum (Mougou and Bougalleb-M'hamdi 2016b).

To control both diseases of citrus, growers in Tunisia used to apply bactericidal compounds. However, this practice could cause serious damage to the environment and human health and also promotes the selection of pathogenic strains with increased tolerance to copper (Brent et al. 1998). For these reasons, biological control deserves serious consideration in the framework of an integrated pest management strategy.

Bacillus subtilis and other Bacillus spp. have been long used as biological control agents against plant bacterial diseases (Chen et al. 2013). Moreover, in recent years, plant bioactive substances have been demonstrated as a new approach to postharvest disease management (Mari 
et al. 2007). Plants produce an array of secondary metabolites, which in many cases have been found to be biologically active, and a rich source of antimicrobial, allelopathic, antioxidant, and bio-regulatory properties (Tripathi et al. 2008). Garlic, Allium sativum, is one of the edible plants which has generated a lot of interest as a medicinal panacea. Previous studies reported the insecticidal, fungicidal, acaricidal, nematicidal, and bactericidal properties of garlic (Lalla et al. 2013). A wide range of microorganisms including gram-positive and gram-negative bacteria (Whitemore and Naidu 2000), fungi, protozoa, and viruses have been shown to be sensitive to crushed garlic preparations (Koch and Lawson 1996). The main antimicrobial constituent of garlic has been identified as an oxygenated sulfur compound, namely thio-2-propene-1-sulfinic acid Sallyl ester, which is usually referred to as allicin (Cavallito and Bailey 1944). Alliin (S-allyl-L-cysteine-sulfoxide) was found to be the stable precursor that is converted to allicin by the action of an enzyme alliinase, which is also present in the cloves of garlic (Ellmore and Feldberg 1994). The antibacterial activity of allicin was reviewed by Ankri and Mirelman (1999).

Plant extracts and antagonistic bacteria could play an important role in plant disease management. Therefore, more information of their in vivo efficiency is needed.

The aim of this study was to investigate the in vitro and in vivo antimicrobial effect of garlic extract and antagonistic bacteria Bacillus spp. against $P$. syringae pv. syringae the causal agent of citrus blast and black pit in Tunisia.

\section{Materials and methods}

\section{Bacterial strains and isolates}

Two strains of $P$. syringae pv. syringae (BAT13 and DAPP-PG115) were used in this study. DAPP-PG115 was obtained from the Bacterial Collection of the Plant Protection Unit, Department of Agricultural, Nutritional and Environmental Sciences, University of Perugia, (Italy). BAT13 strain was isolated from blast necrosis from citrus trees (cv. Thompson Navel) in the region of Menzel Bouzelfa (Cap-Bon) and stored in the collection of plant pathology laboratory at ISA-CM (Tunisia). Identification of bacterial strains was performed by biochemical tests (LOPAT and GATTa) and by comparing 16S rRNA gene sequences with the GenBank database using the Basic Alignment Search Tool (BLAST). Pathogenicity of the strain BAT13 was confirmed on 1-2-year-old citrus (cv. Thompson Navel), which inoculated with a $10^{8} \mathrm{CFU} \mathrm{ml} \mathrm{m}^{-1}$ bacterial suspension and compared to the reference strain DAPP-PG115. Symptoms were characteristic of citrus blast. Necrotic areas were developed and enlarged (unpublished data).

Three bacterial isolates (MBCL2, MBCL3, and FCL2) that proved their antagonistic effect to the pathogen, identified by biochemical test and resembling to Bacillus spp., were obtained from symptomless citrus leaves from orchards located in the region of Takelsa (Tunisia). Antagonistic action of those bacterial isolates was proved by in vitro and in vivo tests.

\section{Garlic storage and extraction}

Garlic bulbs of Allium sativum were purchased from the supermarket and stored at $4{ }^{\circ} \mathrm{C}$ in the dark until required. Axillary buds from the composite garlic bulb were peeled, cleaned, weighed, and roughly crushed. Garlic juice was obtained by squeezing the macerates mixture, using a sterile cheesecloth. The juice was centrifuged, at $4200 \mathrm{rpm}$ for $10 \mathrm{~min}$ in order to separate garlic debris from the liquid and filtrated with a syringe filter $(0.22 \mu \mathrm{m})$. Garlic extract was either used immediately or stored at $4{ }^{\circ} \mathrm{C}$ until use.

\section{Analysis of garlic extract for allicin content}

The content of allicin was determined spectrophotometrically (Jenway 7315), by the reaction with the thiol, 4-mercaptopyridine. The garlic extract was incubated with 4-mercaptopyridine $\left(10^{-4} \mathrm{M}\right)$ in phosphate buffer (50 mM), EDTA (2 mM, pH 7.2), which results in the formation of a mixed disulfide, 4-allylmercaptothiopyridine, and the consequent shift in absorbance at $324 \mathrm{~nm}$ was monitored as described by Miron et al. (2002). The negative control was obtained using the same procedure without garlic extract.

\section{Isolation and identification of the antagonistic bacteria Isolation of the antagonistic bacteria}

During surveys, samples were collected from citrus orchards. Young healthy leaves (10 leaves per plant per orchard were sampled) were taken from different citrus orchards located in Takelsa, Chbika, Menzal Bouzelfa, Sidi Bouali, Bouargoub, Akouda, and El Gobba. The leaves were rinsed with sterile distilled water. Each sample was cut into small pieces (about $2 \times 2 \mathrm{~mm})$, and then, the fragments were surface-disinfected with $95 \%$ ethanol for $3 \mathrm{~min}$. Pieces of tissues were placed in sterilized water and mechanically crushed in a sterile mortar. Then, serial dilutions were made. A loopful of macerate was streaked onto Petri dishes containing the LB (Luria-Bertani) medium and incubated at $25{ }^{\circ} \mathrm{C}$ for 3 days.

\section{Identification of the antagonistic bacteria Potassium hydroxide test $(\mathrm{KOH}) 3 \%$}

The identification of the antagonists was made by biochemical tests. A rapid method $(\mathrm{KOH})$ for the determination of the Gram reactions of bacteria was 
carried out as reported by Suslow et al. (1982). The bacterium was aseptically removed from Petri plates with toothpick, placed on glass slide in a drop of $3 \%$ $\mathrm{KOH}$ solution, and stirred for $10 \mathrm{~s}$ using a quick circular motion of hand.

\section{Catalase test}

A part of the colony in question was transferred to a microscopic slide using a sterile toothpick and mixed with a drop of $\mathrm{H}_{2} \mathrm{O}_{2}$. Production of air bubbles is indicative of catalase activity, whereas no air bubbles indicate a lack of catalase activity.

\section{Oxidase}

This test determines the presence of cytochrome C oxidase enzyme. Kovacs (1956) method was used. A single colony from a freshly streaked LB agar plate was picked and applied with a sterile toothpick to the discs impregnated with a reagent: $N, N, N^{\prime}, N^{\prime}$-tetramethyl-p-phenylenediamine. The production of a distinct purple color in $10 \mathrm{~s}$ was recorded as a positive result.

\section{Hypersensitive reaction (HR) on tobacco plants}

In order to ensure that the antagonistic bacteria are not phytopathogenic agents, a hypersensitivity test was carried out on tobacco leaves (Nicotiana tabacum). The bacterial suspension was spectrophotometrically adjusted to $\left(10^{8} \mathrm{CFU} / \mathrm{ml}\right)$ and was injected into the intercellular space of the leaves using a medical syringe. Controls used in this test were a negative control (sterile distilled water) and positive control (strains DAPP-PG115). The absence of complete collapse of the tissue after $24 \mathrm{~h}$ was recorded as negative reaction.

\section{Assay of in vitro antimicrobial activity of antagonistic bacteria against $P$. syringae \\ Double layer method}

Antagonistic activity towards $P$. syringae pv. syringae of 21 Bacillus isolates (MBCL2, FCL2, GT1, MBCL3, BKT1, GCI1, HT1, FCL1, BKT2, TCK2, TM2, TCK3, MBCL1, MBT1, TCK1, TM4, TM3, TM1, HT2, FCL3, and GCI) obtained was conducted according to the modified method of Vidaver (1976) and Stonier (1960). For each

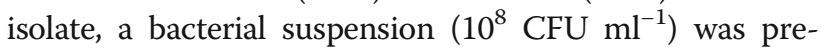
pared in sterile distilled water (SDW); $20 \mu \mathrm{l}$ aliquots were spot-inoculated on LB medium and incubated at $25^{\circ} \mathrm{C}$ for $48 \mathrm{~h}$. At the same day as the spot inoculation, two $P$. syringae pv. syringae strains (BAT13, DAPP-PG115) were streaked onto solid King's B medium and incubated for 2 days at $25{ }^{\circ} \mathrm{C}$. The antagonistic bacteria were then exposed to chloroform vapor for $30 \mathrm{~min}$, and the plates were left open for $15 \mathrm{~min}$ in a flow cabinet. One milliliter of bacterial suspension of the pathogen $\left(10^{8} \mathrm{CFU} \mathrm{ml}{ }^{-1}\right)$ was mixed with $3 \mathrm{ml}$ of LB medium $(0.6 \%$ agar $)$ at $45{ }^{\circ} \mathrm{C}$. This solution was quickly overlain on plates containing the antagonists. Plates were incubated at $25{ }^{\circ} \mathrm{C}$ and checked after 24 to $48 \mathrm{~h}$ for the appearance of inhibition haloes surrounding the antagonist spots.

\section{Agar well diffusion method}

The ability of the antagonist to produce diffusible metabolites was also tested according to the agar well diffusion assay (AWDA) as reported by Tagg and McGiven (1971). The most potential antagonistic bacterial isolates were transferred individually to $50 \mathrm{ml}$ of Luria-Bertani broth medium (LB broth) in a 250-ml Erlenmeyer flask and incubated by shaking at $200 \mathrm{rpm}$ for 4 days at room temperature (RT). Bacterial suspension $\left(1 \mathrm{ml} ; 10^{8} \mathrm{CFU} \mathrm{ml}^{-1}\right)$ of two P. syringae pv. syringae strains (BAT13 and DAPP-PG115) was mixed with $3 \mathrm{ml}$ of LB medium $(0.6 \%$ agar) at $45{ }^{\circ} \mathrm{C}$. This solution was quickly overlain on plates containing LB medium, and wells were then punched in the agar with a sterile steel borer. The potential antagonistic cultures were centrifuged at $15,000 \mathrm{rpm}$ for $30 \mathrm{~min}$ to remove cell debris. After centrifugation, $100 \mu$ l of each sample was aseptically filtered through a $0.45 \mu \mathrm{m}$ filter and added into the prepared wells. The plates were then incubated at $25^{\circ} \mathrm{C}$, and inhibition haloes around the wells were measured.

\section{Assay of in vitro antimicrobial activity of garlic extract against $P$. syringae pv. syringae \\ Disc diffusion method}

The disc diffusion method (Pereira et al. 2006) was used to determine the sensitivity of $P$. syringae towards garlic extract. One milliliter of bacterial sus-

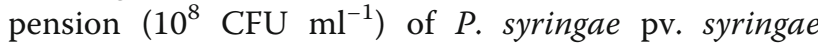
strains (BAT13 or DAPP-PG115) was thoroughly mixed with $\mathrm{LB}$ medium and poured into sterile Petri dish. Many dilutions of the garlic extract were prepared and placed to establish the proportionality of the relationship between the amount of active substance and diameter of inhibition zone. For this, Whatman filter paper disc (6-mm diameter) was placed on LB agar plates surface and an amount of $20 \mu \mathrm{L}$ of pure garlic extract (100\%), 90, 80, 70, 60, $50,40,30,20$, and $10 \%$ dilutions containing 18, 16, $14,12,10,8,6,4$, or $2 \mu \mathrm{l}$ of garlic extract, respectively, were pipetted onto a stack of filter-paper discs. Undiluted garlic extract was considered as the $100 \%$ concentration of the extract. Distilled water was used as negative control. Each sterile disc is impregnated by different concentrations of garlic. Then, plates were incubated overnight at $25{ }^{\circ} \mathrm{C}$.

\section{Agar well diffusion method}

LB medium was poured into each sterile Petri dish. One milliliter of bacterial suspension $\left(10^{8} \mathrm{CFU} \mathrm{m} \mathrm{m}^{-1}\right)$ 
of the two P. syringae pv. syringae strains (BAT13, DAPP-PG115) was mixed with $3 \mathrm{ml}$ of LB medium (0.6\% agar) at $45{ }^{\circ} \mathrm{C}$ (Tagg and McGiven 1971). This solution was quickly overlain on plates containing LB medium, and wells of 6-mm diameter were then punched in the agar with a sterile steel borer. Wells were then punched in the agar with a sterile steel borer. One hundred microliters of garlic extract was aseptically added into the prepared wells. The plates were then incubated at $25{ }^{\circ} \mathrm{C}$, and inhibition haloes around the wells were measured. All experiments were carried out with three replicates and were repeated twice in time.

\section{Assay of in vivo antimicrobial activity of garlic extract and antagonistic bacteria against citrus blast disease development}

Selected strains showing the best in vitro antagonistic activity levels against $P$. syringae were used. In this study, strains MBCL2, MBCL3, FCL2 and undiluted garlic extract were evaluated in vivo. One- and 2-year-old citrus plants of cv. Thompson were used. Plants were kept inside a greenhouse in individual pots filled with a substrate composed of peat and sand $(2 / 3 v$, $1 / 3 v)$. Twelve plants for each treatment were used. Citrus plants were wounded at six sites on the stem. Each wound site was inoculated with $10 \mu \mathrm{l}$ of bacterial suspension $10^{8} \mathrm{CFU} / \mathrm{ml}$ of the strains BAT13 and DAPP-PG115. Three days after inoculation, $10 \mu \mathrm{l}$ of sterile distilled water (control), or a suspension of antagonistic bacteria MBCL2, MBCL3, and FCL2, crude garlic extract or copper sulfate (0.5\%: $0.05 \mathrm{mg} / 10 \mu \mathrm{l}$ SDW) as individual treatment was added to the wounds, which were then covered again by Parafilm M. Measurements of the extend of stem necrosis were taken 10 weeks after inoculation.

\section{Data analysis}

Data were subjected to analysis of variance using IBM SPSS Statistics software (version 23). Mean values among treatments were compared by Duncan's multiple range test at the $5 \%(P=0.05)$ level of significance.

\section{Results and discussion}

\section{Identification of the antagonistic bacteria}

Antagonistic bacteria which exhibited in vitro antibacterial activity against $P$. syringae pv. syringae were biochemically identified. The infiltration of tobacco leaves with the antagonistic bacterial suspensions did not cause hypersensitivity reaction after $24 \mathrm{~h}$ in tobacco leaves, whereas $P$. syringae pv. syringae strain DAPP-PG115 induced a hypersensitive reaction. These results indicated that the used bacterial agent were not plant pathogens. Strains of potential antagonistic agent showed bacterial colony morphology characteristic of Bacillus species. The strains were gram $(+)$, oxidase (-), (HR-) and catalase (+). According to macroscopic characteristics of bacterial strains colonies as well as biochemical characteristics, the antagonistic bacterial strains belong to Bacillus genus according to the keys of De Vos et al. (2009).

\section{In vitro antimicrobial activity of antagonistic bacteria against $P$. syringae pv. syringae Double-layer method}

Analysis of variance of inhibition zone showed highly significant differences between the bacterial treatments $(P=0.05)$. Among 74 strains, 21 showed antibacterial activity against the pathogen. The antagonism of the 21 Bacillus isolates was investigated against the two strains of $P$. syringae pv. syringae (DAPP-PG115 and BAT13). Antimicrobial activity $(\mathrm{mm})$ is expressed as the difference between diameter of inhibition zone and diameter of Bacillus colony (Table 1). The results of the double-layer antagonism

Table 1 Inhibition zone diameter (mm) induced by Bacillus spp. stains against Pseudomonas syringae pv. syringae strains BAT13 and DAPP-PG115

\begin{tabular}{|c|c|c|}
\hline \multirow[t]{3}{*}{ Antagonists (Bacillus spp.) } & \multicolumn{2}{|c|}{ Phytopathogenic bacteria } \\
\hline & \multicolumn{2}{|c|}{ Inhibition zone diameter (mm) } \\
\hline & $\overline{\text { BAT13 }}$ & DAPP-PG115 \\
\hline$\overline{\mathrm{MBCL} 2}$ & $20.66 \pm 0.1 \mathrm{a}$ & $22 \pm 0.1 \mathrm{a}$ \\
\hline $\mathrm{FCL} 2$ & $18 \pm 0.09 b$ & $18.4 \pm 0.09 b$ \\
\hline GT1 & $16 \pm 0.08 c$ & $16.35 \pm 0.05 c$ \\
\hline $\mathrm{MBCL} 3$ & $15.7 \pm 0.05 \mathrm{~cd}$ & $16.33 \pm 0.05 c$ \\
\hline BKT1 & $14.68 \pm 0.05 \mathrm{de}$ & $15.1 \pm 0.1 \mathrm{~d}$ \\
\hline GCl1 & $13.66 \pm 0.05 \mathrm{e}$ & $14 \pm 0.08 \mathrm{e}$ \\
\hline HT1 & $11.66 \pm 0.05 f$ & $12.33 \pm 0.09 f$ \\
\hline FCL1 & $11.68 \pm 0.13 f$ & $12.16 \pm 0.1 \mathrm{f}$ \\
\hline BKT2 & $10.66 \pm 0.08 f$ & $11.33 \pm 0.11 f$ \\
\hline TCK2 & $11 \pm 0.09 f$ & $12.16 \pm 0.07 f$ \\
\hline TM2 & $10.85 \pm 0.05 f$ & $11.85 \pm 0.05 f$ \\
\hline TCK3 & $10.66 \pm 0.1 \mathrm{f}$ & $11.7 \pm 0.04 f$ \\
\hline MBCL1 & $10.68 \pm 0.048 f$ & $11.5 \pm 0.1 \mathrm{f}$ \\
\hline MBT1 & $10.6 \pm 0.053 f$ & $11.55 \pm 0.09 f$ \\
\hline TCK1 & $10.66 \pm 0.10 f$ & $11.33 \pm 0.05 f$ \\
\hline TM4 & $6.66 \pm 0.13 \mathrm{~g}$ & $7.2 \pm 0.16 \mathrm{~g}$ \\
\hline TM3 & $6.68 \pm 0.13 \mathrm{~g}$ & $7.01 \pm 0.04 \mathrm{~g}$ \\
\hline TM1 & $6.33 \pm 0.15 \mathrm{~g}$ & $6.83 \pm 0.07 \mathrm{~g}$ \\
\hline HT2 & $5.83 \pm 0.09 \mathrm{~g}$ & $6.33 \pm 0.05 \mathrm{~g}$ \\
\hline FCL3 & $5.85 \pm 0.07 \mathrm{~g}$ & $6.18 \pm 0.04 \mathrm{~g}$ \\
\hline $\mathrm{GCl}$ & $5.66 \pm 0.05 \mathrm{~g}$ & $6.16 \pm 0.04 \mathrm{~g}$ \\
\hline
\end{tabular}

Small letters are for comparison of means in the same column Means followed by the same letter do not differ significantly $(P=0.05)$ 
tests showed a significant inhibitory effect. Bacillus spp. strain MBCL2 exhibited the highest inhibition zone with values of 20.66 and $22 \mathrm{~mm}$ against BAT13 (Fig. 1) and DAPP-PG115, respectively (Table 1). Moreover, Bacillus spp. strain GCI showed a low antagonistic activity. The diameter of the inhibition zones were 6.1 and $5.6 \mathrm{~mm}$ for DAPP-PG115 and BAT13, respectively. Some studies showed that the difference in efficacy in vitro was due to changes in the nature and concentration of secreted metabolites such as antibiotics (Defago and Haas 1990), lytic enzymes, and siderophores (Bakker et al. 1990).

\section{Agar well method}

Results of the agar well diffusion assays showed that MBCL2 strain exhibited an inhibition zone of $17 \mathrm{~mm}$ and $18 \mathrm{~mm}$ against BAT13 and DAPP-PG115, respectively. For copper sulfate, the respective diameter of inhibition zone was 20.66 and $23 \mathrm{~mm}$ against BAT13 and DAPP-PG115 (Table 3). Thus, the results revealed that the supernatants of antagonistic bacteria had an antagonistic activity lower than copper sulfate $1 \%$.

Previous investigations reported that various bacteria genus are considered as producers of antibiotics or hydrolytic enzymes. Mostly, the bacteria were among the Bacillus genus (Nielsen and Sorensen 1997). In fact, Bacillus species produce secondary metabolites such as antibiotics, lytic enzymes (Frandberg and Schnumer 1994), and volatile and nonvolatile compounds (Parke and Gurian-Sherman 2001).
In vitro antimicrobial activity of garlic extract against $P$. syringae pv. syringae

\section{Disc diffusion method}

The garlic extract contained about $13.4 \mathrm{mg} / \mathrm{ml}$ allicin, as determined spectrophotometrically. The diameter of the inhibition zone given by $20 \mu \mathrm{l}$ of garlic extract at the concentration of $10 \%$ to $100 \%$ varied from 6 to $14 \mathrm{~mm}$ and from 7 to $15 \mathrm{~mm}$ for BAT13 and DAPP-PG115, respectively (Table 2). After applying $20 \mu \mathrm{l}$ of crude extract (approximately $268 \mu \mathrm{g}$ of allicin in $20 \mu \mathrm{l}$ ) or $20 \mu \mathrm{l}$ of dilutions of extract, a clear inhibition halo appeared on Petri plate and the growth of the strains (BAT13, DAPP-PG115) was inhibited by garlic extract placed on seeded agar plates (Fig. 2A and $\mathrm{B})$. The results showed the presence of positive correlation between the increase of garlic extract concentration and the diameter of inhibition zone. The size of the inhibition halo was clearly proportional to the amount of garlic extract applied and showed a linear relationship when plotted against the log of the diameter of the inhibition zone (Fig. 3A and B). The coefficient of determination was 0.83 for BAT13 and 0.88 for DAPP-PG115. Miron et al. (2000) reported that garlic extract has a wide spectrum of antibacterial activity against Gram-negative and Gram-positive bacteria. Recently, it is reported that allicin and its garlic preparations exhibited antibacterial properties at a large spectrum and these bacteria include Aeromonas spp., Bacillus spp., Clostridium spp., Cryptocaryon spp., Escherichia coli, Helicobacter pylori, Klebsiella pneumoniae, Mycobacterium spp.,

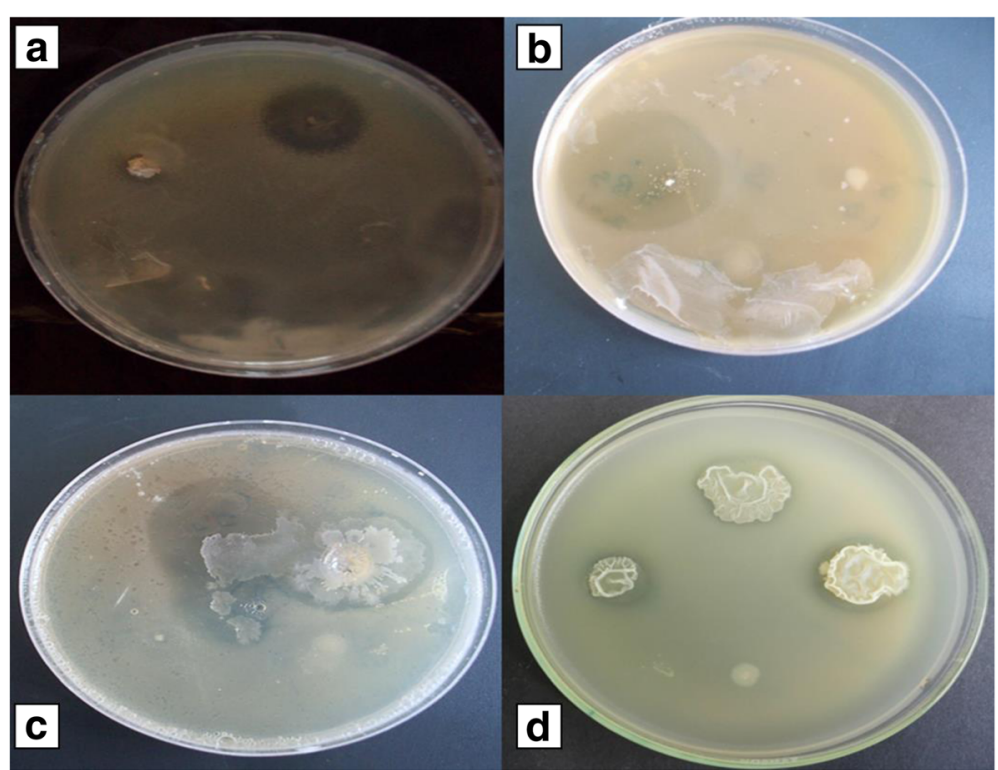

Fig. 1 Inhibition zones induced by Bacillus spp. against Pseudomonas syrinage pv. syringae strain BAT13. a (MBCL3). b (MBCL2). c (FCL2). d (BKT1). (Negative control): strains isolated from citrus leaves 
Table 2 Inhibition zone diameter (mm) induced by garlic extract against Pseudomonas syringae pv. syringae strains BAT13 and DAPP-PG115

\begin{tabular}{|c|c|c|c|c|c|c|c|c|c|c|c|}
\hline \multirow[t]{2}{*}{ Strains } & \multicolumn{11}{|c|}{ Dilution of garlic extract (\%) } \\
\hline & 0 & 10 & 20 & 30 & 40 & 50 & 60 & 70 & 80 & 90 & 100 \\
\hline$\overline{\text { BAT13 }}$ & $0 \mathrm{a}$ & $6 \pm 0.06 b$ & $\begin{array}{l}8 \pm 0.08 \\
c\end{array}$ & $10 \pm 0.06 \mathrm{~d}$ & $10.35 \pm 0.05 d$ & $\begin{array}{l}10.5 \pm \\
0.05 d\end{array}$ & $\begin{array}{l}11.33 \pm 0.08 \\
e\end{array}$ & $e^{11.66 \pm 0.08}$ & $e^{11.83 \pm 0.09}$ & $13 \pm 0.06 f$ & $14 \pm 0.06 \mathrm{~g}$ \\
\hline DAPP-PG115 & $0 \mathrm{a}$ & $\begin{array}{l}7 \pm 0.105 \\
b\end{array}$ & $\begin{array}{l}9 \pm 0.06 \\
c\end{array}$ & $\begin{array}{l}10.5 \pm 0.08 \\
d\end{array}$ & $11 \pm 0.09 \mathrm{~d}$ & $\begin{array}{l}11.2 \pm 0.09 \\
d\end{array}$ & $12.16 \pm 0.04 e$ & $12.33 \pm 0.08 \mathrm{e}$ & $\begin{array}{l}12.85 \pm 0.07 \\
e^{-0.07}\end{array}$ & $14 \pm 0.1 f$ & $15 \pm 0.06 \mathrm{~g}$ \\
\hline
\end{tabular}

Small letters are for comparison of means in the same row

Means followed by the same letter do not differ significantly $(P=0.05)$

Photobacterium spp., Proteus spp., Pseudomonas spp., Salmonella spp., Staphylococcus spp., Streptococcus spp., Vibrio spp., Agrobacterium tumefaciens, Erwinia carotovora, Pseudomonas syringae, and Xanthomonas campestris (Guo et al. 2015).

\section{Agar well diffusion method}

The analysis of variance showed that the results achieved in the presence of the different treatments on the bacterial growth exhibited a highly significant effect. The results of the diffusion in agar test revealed that the garlic extract (approximately $1.34 \mathrm{mg}$ of allicin in $100 \mu \mathrm{l}$ ) exhibited an antibacterial activity against the pathogen. The present study, showed that garlic extract was the most effective treatment against P. syringae pv. syringae strains (BAT13, DAPP-PG115) (Table 3, Fig. 4). The diameters of inhibition zone exhibited by antagonistic bacteria were lower than that induced by copper sulfate. Thus, garlic extract, conducted in vitro, proved to be more effective than copper sulfate $1 \%$ against $P$. syringae. Previous studies reported that $A$. sativum exhibited activity against many pathogenic bacteria and fungi at different rates (Ankri and Mirelman 1999; Pyun and Shin 2006, and Saravanan et al. 2010). The effectiveness of garlic

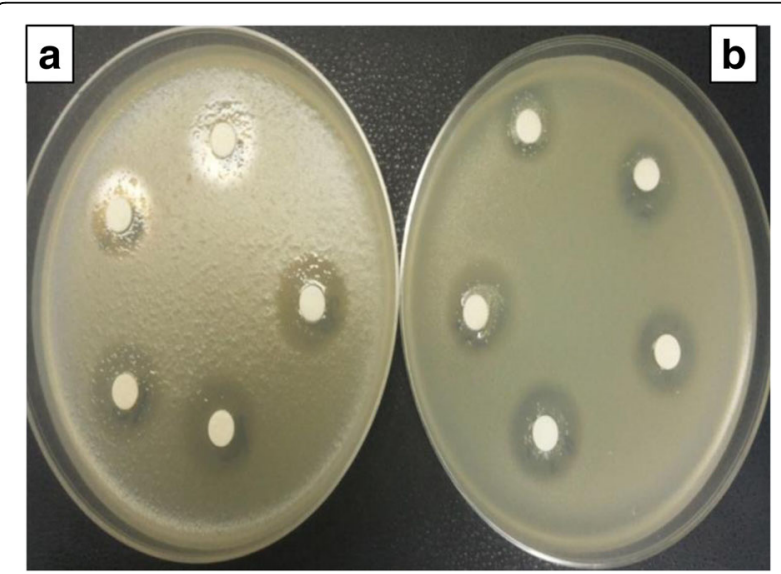

Fig. 2 Antibacterial activity of garlic extract evaluated by the disc diffusion method against DAPP-PG115 (a) and BAT13 (b) extract against a range of plant pathogenic organisms was shown by growth inhibition of the plant pathogenic bacteria Agrobacterium tumefaciens, Erwinia carotovora, Pseudomonas syringae pv. maculicola, $P$. syringae pv. phaseolicola, P. syringae pv. tomato, Xanthomonas campestris pv. campestris (Curtis et al. 2004). Triki et al. (2008) showed that the antimicrobial property of the garlic extract is due to an active molecule which is allicin. This molecule accumulates naturally at ambient temperatures during garlic bulbs storage (Amagase et al. 2001). Allicin crosses the cell membrane easily and undergoes thiol-disulfide exchange reactions with free thiol groups in proteins. It is thought that these properties are the basis of its antimicrobial action (Miron et al. 2000). The action of biological active ingredient of allicin which exhibits its antimicrobial activity mainly by immediate and total inhibition of RNA synthesis, although DNA and protein syntheses are also partially inhibited, suggesting that RNA is the primary target of allicin action (Deresse 2010).

In vivo antimicrobial activity of garlic extract and antagonistic bacteria against citrus blast disease development

Obtained results demonstrated that Bacillus spp. strains MBCL3, FCL2, and MBCL2 reduced the length of stem necrosis caused by the strains (DAPP-PG115 and BAT13). The analysis of the variance showed a highly significant effect of the treatments compared to controls $(P=0.05)$. Typical blast necrosis appeared at inoculated sites of the BAT13 strain showing an average length of stem necrosis of $11 \mathrm{~mm}$, and $9.7 \mathrm{~mm}$ for DAPP-PG115 strain. Bacillus MBCL2 strain reduced the average length of stem necrosis of 56.11 and $62.5 \%$, for BAT13 and DAPP-PG115 strains, respectively. When strain FCL2 was added to the wounds, inoculated with strain BAT13 or DAPP-PG115, a reduction of the average length of stem necrosis was noted with values of 50.13 and 55\%, respectively. In addition, Bacillus spp. MBCL3 strain reduced the mean length of stem necrosis by 53.88 and $61.66 \%$ for BAT13 and DAPP-PG 


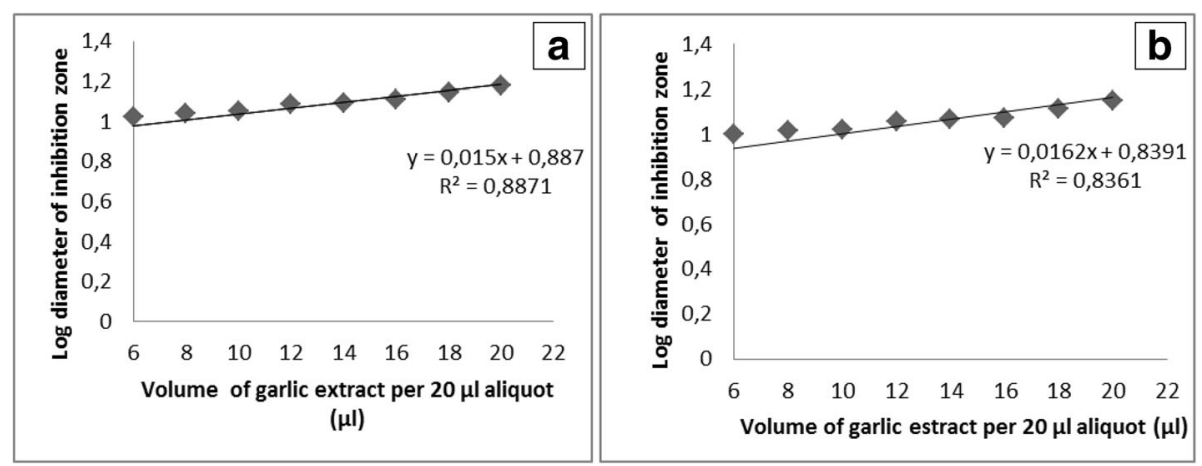

Fig. 3 Regression plot of the log of the inhibition zone diameter on DAPP-PG115 (a) and BAT13 (b) against the volume of garlic extract diluted to $20 \mu \mathrm{l}$

115, respectively. However, copper sulfate generated a reduction of this parameter of 45.83 and $46.38 \%$ for BAT13 and DAPP-PG115, respectively. These results revealed that garlic extract was the most effective treatment for the control of the pathogen. Garlic extract reduced the average length of stem necrosis of 60.55 and $70.83 \%$ for BAT13 and DAPP-PG115 isolates, respectively (Figs. 5 and 6, Table 4).

The biological control of $P$. syringae pv. syringae the causative agent of citrus blast and black pit disease under in vitro and in vivo conditions has not been studied. In vivo experiments showed that the antagonistic bacteria (MBCL3, FCL2, and MBCL2) reduced the length of stem necrosis.

Shafi et al. (2017) mentioned that the use and number of antagonistically important Bacillus species is increasing very rapidly. Bacillus species have a unique ability to replicate rapidly, resistant to adverse environmental conditions as well as they have a broad spectrum of biocontrol ability. Bacillus spp. play a direct role in resistance to phytopathogenic organisms through the production of extracellular antimicrobial antibiotics, toxins, hydrolases and lipopeptides (Bardin et al. 2015).

Table 3 Antibacterial activities of garlic extract, Bacillus spp. and copper sulfate against BAT13 and DAPP-PG115

\begin{tabular}{lll}
\hline Treatments & \multicolumn{2}{l}{ Phytopathogenic bacteria } \\
\cline { 2 - 3 } & BAT13 & DAPP-PG115 \\
& Agar well diffusion & \\
\hline BKT1 & $13.33 \pm 0.05 \mathrm{a}$ & $13.5 \pm 0.08 \mathrm{a}$ \\
MBCL3 & $14 \pm 0.05 \mathrm{a}$ & $14.33 \pm 0.12 \mathrm{a}$ \\
FCL2 & $15.5 \pm 0.12 \mathrm{~b}$ & $15.83 \pm 0.11 \mathrm{~b}$ \\
MBCL2 & $17 \pm 0.1 \mathrm{c}$ & $18 \pm 0.09 \mathrm{c}$ \\
Garlic extract & $24.66 \pm 0.13 \mathrm{e}$ & $32.83 \pm 0.15 \mathrm{e}$ \\
GT1 & $13.83 \pm 0.11 \mathrm{a}$ & $14.16 \pm 0.09 \mathrm{a}$ \\
Copper sulfate $1 \%$ & $20.66 \pm 0.1 \mathrm{~d}$ & $23 \pm 0.08 \mathrm{~d}$ \\
\hline
\end{tabular}

Small letters are for comparison of means in the same column Means followed by the same letter do not differ significantly $(P=0.05)$
It was proved that many antibiotics produced by Bacillus subtilis were wide spectra (Vanneste 2000) such as glycopeptide that has a role in plant growth stimulation. It has been reported that some $B$. subtilis strains can effectively suppress the Ralstonia wilt disease in several plant hosts (Aliye et al. 2008 and Ji et al. 2008).

Furthermore, the commercial biofungicide, Serenade, which contains $B$. subtilis as an active compound, is reported to be effective against many pathogenic bacteria, including Erwinia, Pseudomonas, and Xanthomonas strains. The mechanism of this antibacterial effect is uncertain, although it is known that $B$. subtilis can produce a variety of antibacterial agents, including a broad spectrum of lipopeptides, such as surfactin, that are potent biosurfactants (Peypoux et al. 1999).

The antimicrobial effect of the natural substances of A. sativum extract was also confirmed by in vivo tests on plants inoculated with suspension of $P$. syringae strains. A. sativum extract seemed to be the most effective treatment, when compared to the untreated control and the copper sulfate. In addition, Hassan and El-Meneisy (2014) demonstrated that garlic extract reduced the severity of the disease of bacterial Halo blight of bean caused by P. syringae pv. phaseolicola.

In the same sense, Balestra et al. (2009) reported that $A$. sativum extract reduced the disease incidence and disease severity caused by $P$. syringae pv. tomato, Xanthomonas vesicatoria and Clavibacter michiganensis subsp. michiganensis.

It was reported that in vivo tests of aqueous extracts of A. sativum and Ficus carica fruits showed a reduction of the survival and the damages caused by $P$. syringae pv. syringae, and Pseudomonas viridiflava bacterial pathogens of kiwifruit (Balestra et al. 2008).

In addition, to any directly antimicrobial effects of allicin on pathogens in planta, it is conceivable that garlic extract might contain substances which are able to induce systemic acquired resistance (SAR) in the host. Thus, when plants are sprayed with garlic extract or 


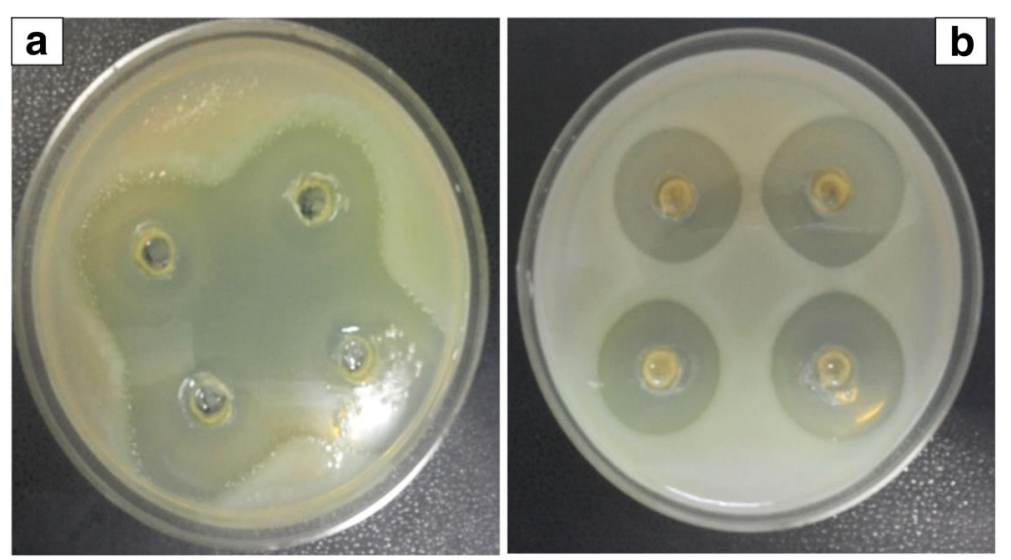

Fig. 4 Inhibition zones induced by garlic extract against Pseudomonas syringae pv. syringae strains DAPP-PG115 (a) and BAT13 (b)

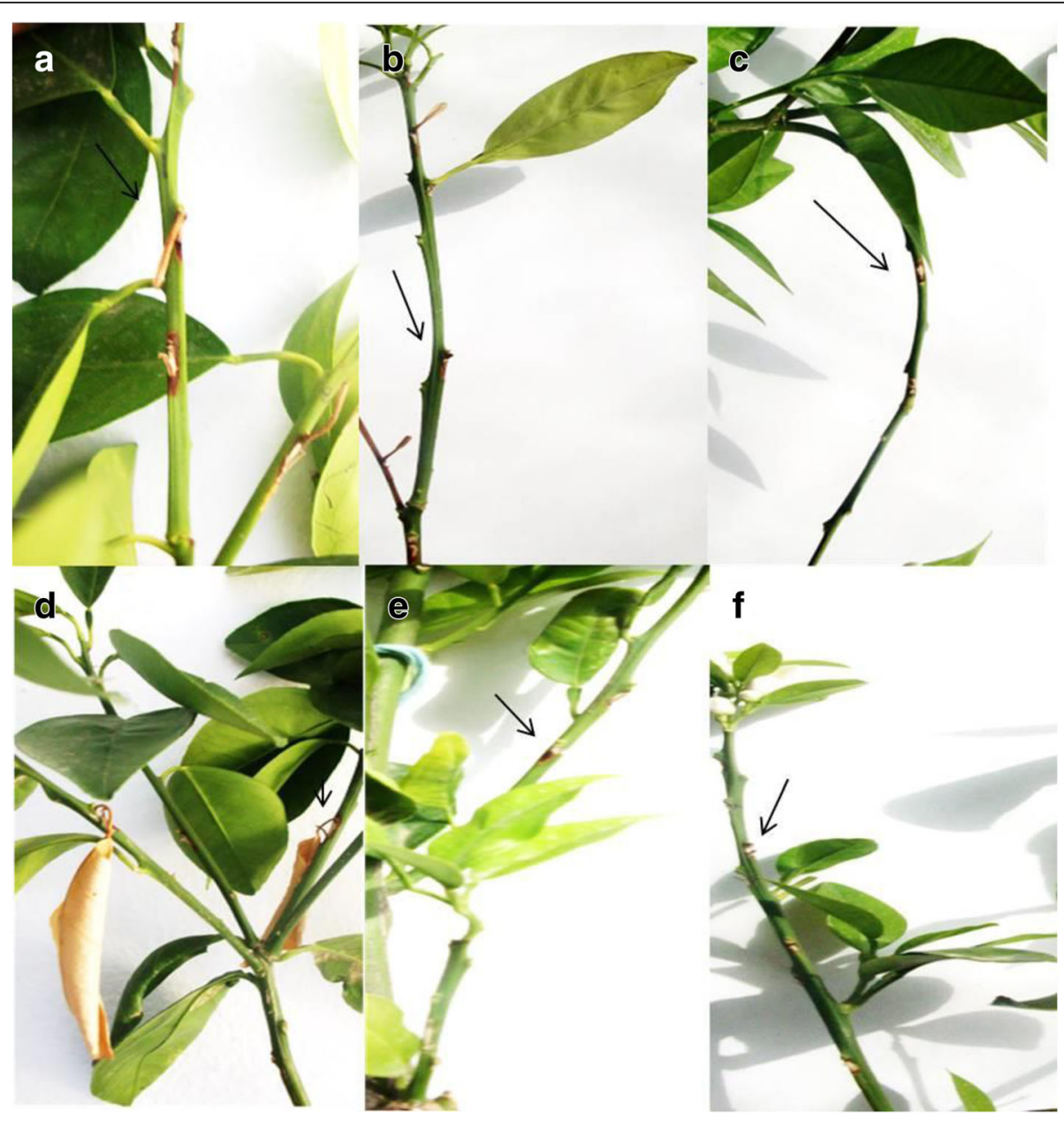

Fig. 5 Blast development after 10 weeks of inoculation with Pseudomonas syrinage pv. syringae strain BAT13: a control, b plant treated with 0.5\% CuSO4, c plant treated with FCL2, d plant treated with MBCL3, e Plant treated with MBCL2, $\mathbf{f}$ plant treated with garlic extract (approximately $134 \mathrm{\mu g} \mathrm{ml}^{-1}$ of allicin in $\left.10 \mu \mathrm{l}\right)$ 


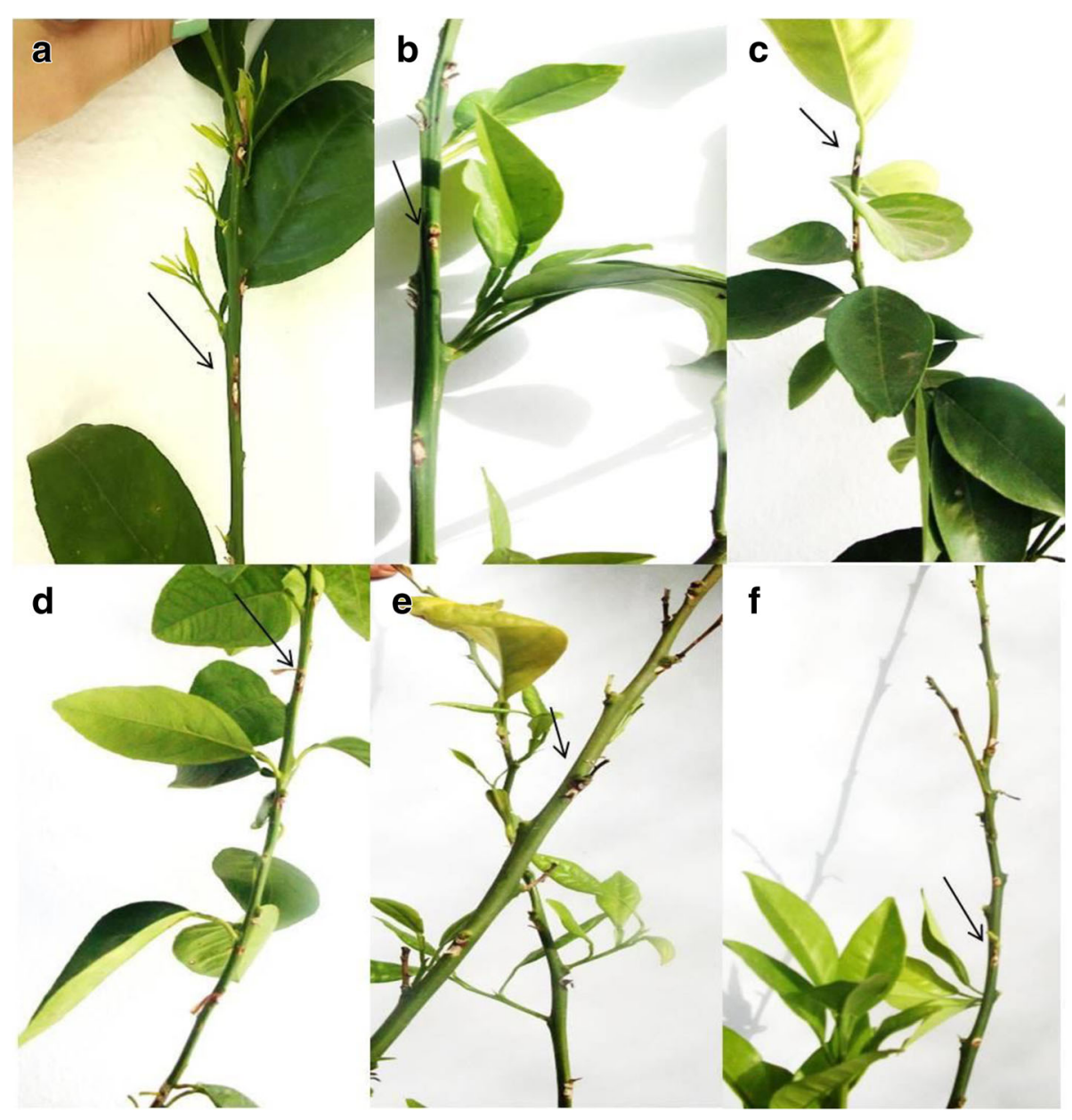

Fig. 6 Blast development after 10 weeks of inoculation with Pseudomonas syrinage pv. syringae strain DAPP-PG115: a control, b plant treated with $0.5 \%$ CuSO4, c plant treated with FCL2, d plant treated with MBCL3, e Plant treated with MBCL2, $\mathbf{f}$ plant treated with garlic extract (approximately $134 \mathrm{\mu g} \mathrm{ml}^{-1}$ of allicin in $\left.10 \mu \mathrm{l}\right)$

Table 4 Effect of different treatments on the length of stem necrosis

\begin{tabular}{|c|c|c|c|c|}
\hline \multirow[t]{3}{*}{ Treatments } & \multicolumn{4}{|l|}{ Phytopathogenic bacteria } \\
\hline & \multicolumn{2}{|l|}{ BAT13 } & \multicolumn{2}{|l|}{ DAPP-PG115 } \\
\hline & Stem necrosis length $(\mathrm{mm})$ & $\%$ of reduction & Stem necrosis length $(\mathrm{mm})$ & $\%$ of reduction \\
\hline Garlic extract & $4.5 \mathrm{e}$ & $60.55 \mathrm{e}$ & $2.6 \mathrm{e}$ & 70.83 e \\
\hline MBCL3 & $5.2 d$ & $53.88 d$ & $3.5 d$ & $61.66 d$ \\
\hline FCL2 & $5.5 \mathrm{c}$ & $50.13 \mathrm{c}$ & $4.5 \mathrm{c}$ & $55 c$ \\
\hline MBCL2 & $5 d$ & $56.11 d$ & $3.5 d$ & $62.5 \mathrm{~d}$ \\
\hline Copper sulfate & $6 b$ & $45.83 \mathrm{~b}$ & $5.1 \mathrm{~b}$ & $46.52 \mathrm{~b}$ \\
\hline control & $11 \mathrm{a}$ & $0 \mathrm{a}$ & $9.7 a$ & $0 \mathrm{a}$ \\
\hline
\end{tabular}


treated with allicin via the vapor phase before inoculation with a pathogen, SAR in the host might be contributing to any observed reduction in disease. The SAR state is accompanied by the accumulation of molecular markers such as mRNA for pathogenesis-related proteins and salicylic acid (Uknes et al. 1992).

The present study is the first to show the antimicrobial effect of garlic extract and antagonistic bacteria Bacillus spp. against $P$. syringae pv. syringae affecting citrus. According to this study, plant extract and antagonistic bacteria (Bacillus spp.) may be good alternatives of the used fungicides to control such diseases.

\section{Conclusions}

Garlic, A. sativum, extract and three strains of Bacillus spp. were found to have inhibitor effect against the growth of $P$. syringae pv. syringae under in vitro as well as disease development under greenhouse conditions. Referring to the obtained results, it could conclude that the antimicrobial activity of applied treatments showed effectiveness, gave interesting opportunities to substitute the copper compounds treatments, that usually been used in organic agriculture. It is of interest to use such treatments to control Pseudomonas syringae pv. syringae causative agent of citrus blast and black pit disease.

\section{Acknowledgements}

The authors are very grateful to the laboratory of phytopathology, Department of Biological Sciences and Plant Protection, at High Agronomic Institute of Chott Mariem. This research was supported by UR13AGR03, University of Sousse, Tunisia. The experiments comply with the current laws of the country in which they were performed.

\section{Funding}

This investigation was funded by the research unit UR13AGR03, University of Sousse Tunisia.

\section{Availability of data and materials}

All data are available at the article and the materials used in this work are of high quality and grade.

\section{Authors' contributions}

Both authors contributed equally to this work. Both authors read and approved the final manuscript.

\section{Ethics approval and consent to participate}

Not applicable.

\section{Consent for publication}

Not applicable.

\section{Competing interests}

The authors declare that they have no competing interests.

\section{Publisher's Note}

Springer Nature remains neutral with regard to jurisdictional claims in published maps and institutional affiliations.
Received: 12 April 2018 Accepted: 27 June 2018

Published online: 20 July 2018

\section{References}

Abdellatif E, Kaluzna M, Helali F, Cherif M, Janse JD, Rhouma A (2015) First report of citrus bacterial blast and citrus black pit caused by Pseudomonas syringe pv. syringae in Tunisia. New Dis Rep 32:35

Aliye N, Fininsa C, Hiskias Y (2008) Evaluation of rhizosphere bacterial antagonists for their potential to bioprotect potato (Solanum tuberosum) against bacterial wilt (Ralstonia solanacearum). Biol Control 47:282-288

Amagase H, Petesch BL, Matsuura H, Kasuga S, Itakura Y (2001) Intake of garlic and its bioactive components. J Nutr 131:955-962

Ankri S, Mirelman D (1999) Antimicrobial properties of allicin from garlic. Microbes Infect 2:125-129

Bakker PAHM, van Peer R, Schippers B (1990) Specificity of siderophores and siderophore receptors and biocontrol by Pseudomonas spp. In: Hornby D (ed) Biological control of soil-borne plant pathogens. CAB International, Wallingford, pp 131-142

Balestra GM, Heydari A, Ceccarelli D, Ovidi E, Quattrucci A (2009) Antibacterial effect of Allium sativum and Ficuscarica extracts on tomato bacterial pathogens. Crop Prot 28:807-811

Balestra GM, Rossetti A, Quattrucci A (2008) Biological control of kiwifruit and tomato bacterial pathogens. In: $16^{\text {th }}$ IFOAM Organic World Congress. Modena, Italy, pp 3-6

Bardin M, Ajouz S, Comby M, Lopez-Ferber M, Graillot B, Siegwart M, Nicot PC (2015) Is the efficacy of biological control against plant diseases likely to be more durable than that of chemical pesticides? Front Plant Sci 6:566

Beiki F, Busquets A, Gomila M, Rahimian H, Lalucat J, García-Valdés E (2016) New Pseudomonas spp. are pathogenic to citrus. PLoS One 11:1-16

Boubaker A (1986) Etude préliminaire de la bactériose (P. syringae) isolée à partir de jeunes bigaradiers. Revue de I'INAT 1:69-79

Brent K, Hollomon DW, Federation GCP (1998) Fungicide resistance: the assessment of risk. GCPF, Brussels, pp 1-146

Cavallito C, Bailey JH (1944) Allicin, the antibacterial principle of Allium sativum. Isolation, physical properties and antibacterial action. Am Che Soc 66:1950-1951

Chen Y, Yan F, Chai Y, Liu H, Kolter R, Losick R, Guo JH (2013) Biocontrol of tomato wilt disease by Bacillus subtilis isolates from natural environments depends on conserved genes mediating biofilm formation. Environ Microbiol 15:848-864

Curtis H, Noll U, Störmann J, Slusarenko AJ (2004) Broad-spectrum activity of the volatile phytoanticipinallicin in extracts of garlic (Allium sativum L.) against plant pathogenic bacteria, fungi and Oomycetes. Physiol Mol Plant Pathol 65: 79-89

De Vos P, Garrity GM, Jones D, Krieg NR, Ludwig W, Rainey FA, Schleifer KH, Whitman WB (2009) Bergey's manual of systematic bacteriology, 2nd edn. Springer, New york, p 119

Defago G, Haas D (1990) Pseudomonads as antagonists of soilborne plant pathogens: modes of action and genetic analysis. Soil Biochem 6:249-291

Deresse D (2010) Antibacterial effect of garlic (Allium sativum) on Staphylococcus aureus: an in vitro study. Asian J Med Sci Sciences 2:62-65

DGPA. (2016) Report of general direction of agricultural production. Tunisian Ministry of Agriculture

Ellmore GS, Feldberg RS (1994) Alliin lyase localization in bundle sheaths of garlic clove (Allium sativum). Am J Bot 81:89-94

Fawcett HS, Horne WT, Camp AF (1923) Citrus blast and black pit. Calif Agric Exp Sta $5: 1-24$

Frandberg E, Schnumer J (1994) Chitinolytic properties of Bacillus pabuli K I. Appl Microbiol 76:361-367

Guo JJ, Kuo CM, Hong JW, Chou RL, Lee YH, Chen TI (2015) The effects of garlicsupplemented diets on antibacterial activities against Photobacterium damselae subsp. Piscicida and Streptococcus iniae and on growth in Cobia. Rachycentron Canadum. Aquaculture 435:111-115

Hassan OE, El-Meneisy AZA (2014) Biocontrol of halo blight of bean caused by Pseudomonas phaseolicola. Int J Virol 10:235-242

Ji XL, Lu GB, Gai YP, Zheng CC, Mu ZM (2008) Biological control against bacterial wilt and colonization of mulberry by an endophytic Bacillus subtilis strain. FEMS Microbiol Ecol 65:565-573

Koch HP, Lawson LD (1996) Garlic, the science and therapeutic application of Allium sativum L. and related species. In: Retford DC (ed) Garlic: The science and therapeutic application of Allium sativum $L$. and related species Williams and Wilkins, Baltimore, p 329 
Kovacs N (1956) Identification of Pseudomonas pyocyanea by the oxidase reaction. Nature 178:703

Lalla FD, Ahmed B, Omar A, Mohieddine M (2013) Chemical composition and biological activity of Allium sativum essential oils against Callosobruchus maculatus. Env Sci Toxicol Food Tech 3:30-36

Mari M, Neri F, Bertolini P (2007) Novel approaches to prevent and control postharvest diseases of fruits. Stewart Postharvest Rev 6:4

Miron T, Rabinkov A, Mirelman D, Wilchek M, Weiner $L$ (2000) The mode of action of allicin: its ready permeability through phospholipid membranes may contribute to its biological activity. Biochim Biophys Acta 1463:20-30

Miron T, Shin I, Feigenblat G, Weiner L, Mirelman D, Wilchek M, Rabinkov A (2002) A spectrophotometric assay for allicin, alliin and alliinase (alliinlyase) with a chromogenic thiol: reaction of 4- mercaptopyridine with thiosulfinates. Anal Biochem 307:76-83

Mougou I, Bougalleb-M'hamdi N (2016a) Differential susceptibility of citrus cultivars toward blast and black pit in Tunisia caused by Pseudomonas syringae pv. syringae. European J Biotechnol Biosci 4:17-24

Mougou I, Bougalleb-M'hamdi N (2016b) Detection, survival, and source of inoculum of Pseudomonas syringae pv. syringae from weeds and plant debris in relation to epidemiology of bacterial citrus blast and black pit in Tunisia. Br Microbiol Res J 16:1-10

Nielsen P, Sorensen J (1997) Multi-target and medium-independent fungal antagonisms by hydrolytic enzymes in Paenibacillus polymyxa and Bacillus pumilus strains from barley rhizosphere. FEMS Microbiol Ecol 22:183-192

Parke JL, Gurian-Sherman D (2001) Diversity of the Burk-holderiacepacia complex and implications for risk assessment of biological control stains. Annu Rev Phytopathol 39:225-258

Pereira LS, Cardoso VJR, Medeiros RPL, Pereira LM, Menezes LVL, Satiro XH, Olivera LE (2006) Antimicrobial activity of Indigofera suffruticosa. eCAM 3: 261-265

Peypoux F, Bonmatin JM, Wallach J (1999) Recent trends in the biochemistry of surfactin. Appl Microbiol Biotechnol 51:553-563

Pyun MS, Shin S (2006) Antifungal effects of the volatile oils from Allium plants against Trichophyton species and synergism of the oils with ketoconazole. Phytomedicine 13:394-400

Saravanan P, Ramya V, Sridhar H, Balamurugan V, Umamaheswari S (2010) Antibacterial activity of Allium sativum L. on pathogenic bacterial strains. Glob Vet 4:519-522

Shafi J, Tian H, Ji M (2017) Bacillus species as versatile weapons for plant pathogens: a review. Biotechnol Biotechnol Equip 31:446-459

Snowdon AL (1990) A colour atlas of post-harvest diseases and disorders of fruit and vegetables. In: Snowdon AL (ed) General introduction and fruits. Wolfe Publishing, London, pp 1-302

Stonier T (1960) Agrobacterium tumefaciens Conn II. Production of an antibiotic substance. J Bacteriol 79:889-898

Suslow TV, Schroth MN, Isaka MH (1982) Application of rapid method for gram differentiation of plant pathogenic and saprophytic bacteria without staining. Phytopathol 72:917-918

Tagg JR, McGiven AR (1971) Assay system for bacteriocins. Appl Microbiol 21:943

Triki MA, Krichen W, Hassaïri A, Aouissaoui H, Drira N (2008) Etude de l'activité antifongique de l'extrait d'ail pour lutter contre quelques champignons telluriques, agents de pourriture des racines de l'olivier. Symposium International sur la Protection intégrée de l'olivier, Sousse

Tripathi P, Dubey NK, Shukla AK (2008) Use of some essential oils as postharvest botanical fungicides in the management of grey mould of grapes caused by Botrytis cinerea. World J Microbiol Biotechnol 24:39-46

Uknes S, Mauch-Mani B, Moyer M, Potter S, Williams S, Dincher S, Chandler D, Slusarenko A, Ward E, Ryals J (1992) Acquired resistance in Arabidopsis. Plant Cell 4:645-656

Vanneste $\lrcorner$ (2000) Fire blight. The disease and causative agent, Erwinia amylovora. CABI Publications, Wallingford, p 370

Vidaver AK (1976) Prospects for control of phytopathogenic bacteria by bacteriophages and bacteriocins. Annu Rev Phytopathol 14:465-541

Whitemore BB, Naidu AS (2000) Thiosulfinates. In: Naidu AS (ed) Natural food antimicrobial systems. FL: CRC Press, Boca Raton, pp 265-380

\section{Submit your manuscript to a SpringerOpen ${ }^{\circ}$ journal and benefit from:}

- Convenient online submission

- Rigorous peer review

- Open access: articles freely available online

- High visibility within the field

- Retaining the copyright to your article

Submit your next manuscript at $\boldsymbol{\nabla}$ springeropen.com 